\title{
A case of somnambulism?
}

\author{
Paul Batchelor
}

Honorary Clinical Professor, School of Medicine, University of Central Lancashire

The BDJ Upfront section includes editorials, letters, news, book reviews and interviews. Please direct your correspondence to the News Editor,

Kate Quinlan at k.quinlan@nature.com. Press releases or articles may be edited, and should include a colour photograph if possible.

W ith the collapse of Finest Dental Care the risks of the use of incorporation within the dental care sector is dawning. Incorporation is the process that results in a legal entity that separates an organisation's assets and income from its owners and investors. Advantages to incorporation for the owners including personal asset protection and tax flexibility exist but so do downsides for the public.

Since the relaxation of the regulations by the General Dental Council (GDC) in 2006 the number and market size of such entities has grown substantially. Estimates currently suggest that over $25 \%$ of dental practices are part of a Dental Body Corporate (DBC) the size varying enormously with a small number accounting for the majority of DBC held NHS contracts. Such developments are all too predictable. Stoesz and Karger ${ }^{1}$ when reporting on the impact of corporatisation of welfare arrangements in the US suggested that three underlying consequences arose: standardisation, commodification, and the oligarchic nature of human services features all too familiar for those working for the larger DBCs. They also highlighted that a small number of firms are in a stronger position to dictate the terms of service provision than a larger number of competing firms.

The Public Accounts Committee (PAC) nearly 10 years ago stated in their report ${ }^{2}$ following the demise of Southern Cross, the largest corporate care home company, that there is no clarity about the consequences of failure of large-scale providers. The Committee made a number of recommendations including greater clarity over what will happen in cases of large-scale provider failure. The Department of Social Services acknowledged that they had insufficient powers and must decide what preand- post-failure regime powers were needed to be put in place to protect care home residents if or when large-scale providers fail.

Crucially, the PAC noted that the Department did not monitor the financial health of large-scale providers. The Department was unaware of the financial difficulties at Southern Cross until the company made a formal approach to it. The PAC recommended that the Department must decide how it will monitor the financial health of large-scale providers so that it has early warning of difficulties and develop ways in which it might respond should problems arise, so that the interests of both social care users and the taxpayer are protected.

\section{'For the larger arrangements, while benefits to the owners are greater, for the public failure has more serious consequences'}

In the dental sector three key issues exist in respect to corporate providers: their size, funding and governance arrangements. Dental providers exist in four groupings: the single-handed practitioner; the 'group' practice; the 'group' with additional businesses that are limited to dentistry; and the 'group' in which dental provision is but one part of the organisation. For each grouping the risks and benefits of corporate status are different. For the single-handed practitioner, the benefits to the owner are limited; the consequences of failure for the public similar. However, for the larger arrangements, while benefits to the owners are greater, for the public failure has more serious consequences. It is no longer a few hundred individuals who may need to seek care but thousands.

The situation in the UK is not unique. Europe has seen the collapse of corporate structures including Vitaldent. Its initial clinic in Madrid expanded throughout Spain and subsequently into Italy, Portugal and Poland. Then opening in New York it failed and eventually closed across the Atlantic.
The financial risk aspects have been highlighted by Templeman. ' A parent company may spawn a number of subsidiary companies, all controlled directly or indirectly by the shareholders of the parent company. If one of the subsidiaries companies...turns out to be the runt of the litter and declines into insolvency to the dismay of its creditors, the parent company and other subsidiary companies may prosper to the joy of the shareholders without any liability for the debts of the insolvent subsidiary.'

For DBCs in which dental provision is simply one aspect of the organisation, 